\title{
Восстания в Казахстане против царской власти в 1916 году и советской политики в 1921-22 гг.: сходства и различия (на основе материалов Акмолинского и Атбасарского уездов)
}

\author{
ТЛЕГЕН САДЫКОВИЧ САДЫКОВ - САЯН ТАЛГАТУЛЫ НАБИЕВ
}

Евразийский национальный университет им. Л.Н. Гумилева, 2. Нур-Султан, Республика Казахстан

Kazakhstanian uprisings against tsarist government in 1916 and Soviet policy in 1921-1922: analogy and specifics (based on material of Akmola and Atbasar uyezd)

Abstract: The article describes the causes and conditions leading to the eruption of the uprisings in 1916 and during 1921-1922 in Kazakhstan. The study analyses moods of the masses represented as the driving force of the national liberation uprisings of this period. Specific historical facts based on archival research and reconnaissance of historical sources are presented here as well. In the end of the study, the authors analyze internal context of the uprisings against tsarist dominance (1916) and the establishment of Soviet power (1921-1922) in the country, revealing analogous features and specifics of researched events.

Keywords: tsarist policy in Kazakhstan, period of war communism in Kazakhstan, uprisings in Kazakhstan in 1916 and 1921-1922, national liberation movements in Central Asia.

DOI: https://doi.org/10.24040/ahn.2020.23.02.167-181

Введение. В исторических исследованиях независимого Казахстана особенно актуально всестороннее изучение проблематики национально-освободительных движений, определение места и роли видных деятелей - лидеров этих движений в гражданской и политической истории казахского народа. Поэтому события 1916 года выступают в отечественной истории одной из значимых вех в борьбе за свободу нации, занимают важное место в комплексном исследовании истории казахского народа. В этом контексте задачи восстановления исторической истины, объективной оценки с новых позиций освободительной борьбы того периода возлагают большую ответственность на сообщество историков.

Исследование внутренней взаимосвязи восстаний против царского правительства (1916 г.) и советской власти (1921-1922 гг.) предоставляет возможности для восстановления исторической 
истины. Выявление сходных черт и особенностей указанных событий посредством введения в научный оборот новых сведений требует пересмотра хронологических рамок восстаний, прошедших в первой четверти XX века, оценки роли их руководителей. В частности, восстания 1916 года в Акмолинском и Атбасарском уездах, по административно-территориальному статусу относившиеся в то время к Акмолинской области, продолжались до первых дней правления советской власти. Для этого актуальным является вопрос определения характера восстаний тех лет, оценки исторической значимости указанных событий, их причин, движущей силы.

Сведения и методы исследования. В процессе написания статьи были исследованы материалы Центрального государственного архива Республики Казахстан, Президентского Архива Республики Казахстан, госархивов Акмолинской и Костанайской областей, архивов городов Нур-Султан, Жезказган, Кызылорда, Аркалык. Некоторые из этих материалов вводятся в научный оборот впервые.

Сведения о социально-экономическом и политическом развитии исследуемого края в рассматриваемые периоды взяты из следующих сборников и журналов: «Журнал совещания о землеустройстве киргиз» (С. Петербург, 1907), «Киргизское хозяйство в Акмолинской области T-V» (С. Петербург, 1910), «Сельскохозяйственный обзор Акмолинской области за 1915 г.», (Омск, 1917), «Обзор сельскохозяйственный жизни заселяемых районов Азиатской России за 1913 г.», (С. Петербург, 1914), «Экономическая жизнь Киргизского края» (1921), «Известия Киргизского областного комитета» (1922), «Стенографический отчет 11-го съезда Советов КирССР 4-10 октября 1921 года».

Были также использованы сведения из первого сборника документов и материалов под редакцией Б.С. Сулейменова «Восстание 1916 года в Казахстане» ${ }^{1}$ и сборника документов «Восстание 1916 года в Средней Азии и Казахстане»², изданного в 1960 году. Значительная часть документов, вошедших в указанные издания в свое время были опубликованы впервые.

Для издания сборника «Восстание 1916 года в Казахстане» был консолидирован большой коллектив ученых-историков, в работе нашли отражение свыше 500 документов из архивов республик Средней Азии, Казахстана, Москвы. В указанных сборниках встречается много сведений касательно исследуемого нами региона.

\footnotetext{
${ }^{1}$ Царская колонизация в Казахстане. По материалам русской периодической печати ХІХ века. Сост. Ф.М. Оразаев. Алматы: Рауан, 1995, с. 368.

2 АЛДАБЕРГЕНОВ, К.М.: Направления и итоги колониальной политики России в Казахстане (По материалам 1860-1918 г.г.). Алматы: Рауан, 2000, с. 285.
} 
Особенно точно описывают ход событий, картину тех лет дополняют телеграммы предводителей Атбасарской и Акмолинской карательных армий. В частности, можно привести сведения по известному Каражарскому сражению, состоявшемуся 23 сентября 1916 года в Атбасарском уезде между ополченцами волости Баганалы и карательной армией ${ }^{3}$.

Несмотря на то, что в советское время на страницах печатных изданий публиковалось достаточно фактов из жизни руководителей, видных фигур восстания 1916 года и воспоминаний о них, специальных научных исследований в данном направлении не проводилось. Хотя в отдельных статьях и упоминаются имена героев восстания 1916 года в Атбасарском уезде - Хасена Сандыбаева, Ахмета ишана Оразаева, М. Жанайдарова, алашординца С. Жылкыайдарова, Ж. Ниязбекова и других - их жизнь и борьба должным образом не изучена по сей день, даже в период суверенитета и независимости Казахстана. В трудах А. Байжана, М. Сулейменова ${ }^{4}$ говорится об еще одной известной личности восстания - Кейки Кокембаеве, 5 однако там нет сведений о борьбе Кейки батыра в 1920-22 годах в Атбасарском регионе.

Публикация в 1997 году сборника документов и материалов «Суровый 1916 год» в двух томах считается большим достижением для расширения документальной основы данной темы ${ }^{6}$. Кроме того, в ходе работы над статьей были использованы материалы, сборники, воспоминания, опубликованные в годы независимости.

Рассматриваемый нами период также находился в центре внимания западных исследователей. Начиная с 80-х годов XX века, интерес западных ученых к этому вопросу возрос. Мнения некоторых из них сошлись в том, что «сталинская политика имела целенаправленный характер, чтобы как этнос, как класс уничтожить казахов, украинцев и другие нации». Конечно, на переднем плане стоит книга британского историка Роберта Конквеста «Жатва Скорби: советская коллективизация и террор голодом», увидевшая свет в 1986 году. «Голод в Казахстане был создан искусственно, другими словами, он повторяет голод 1921 года, возникнув в результате непродуманной и идеологизированной политики кол-

\footnotetext{
3 дУЛАТОВА, Д.И.: Историография дореволюционного Казахстана. Алма-Ата: Наука, 1984, с. 480-481.

${ }_{4}^{4} 1916$ год. Рассказы, стихи и эпосы. Алматы: Рауан, 1996, с. 130, 150.

${ }^{5}$ См.: БЕКМАГАНБЕТОВ, У. Ж.: Кейки (Нурмаганбет) Кукембайулы - одна из первых жертв советской репрессивной системы в Казахстане. In: Acta historica Neosoliensia, 22(1), 2019, с. 78-88.

${ }^{6}$ Суровый 1916 год: Сборник документов и материалов. Т.2. Алматы: Казахстан, 1998, c. 58.
} 
лективизации. Известно, что последствием этой политики явилось массовое восстание народа», - пишет Р. Конквест ${ }^{7}$.

В том же ключе рассуждает и американский эксперт Марта Брилл Олкотт. В своей книге «Коллективизация в Казахстане» она указывает, что «самая большая проблема для советолога - это понять и правильно интерпретировать события 1930-х годов»8. А в 1997 году был издан первый фундаментальный справочный труд международного коллектива историков С. Куртуа, Н. Верта, Ж-Л. Панне, А. Пачковского, К. Бартошека, Ж.-Л. Марголена под названием «Черная книга коммунизма: преступления, террор, репрессии». Авторы книги «Годы голода. Советское сельское хозяйство. 1931-1933 гг.» Р.У. Дэвис и С.Г. Уиткрофт на основе документальных сведений и воспоминаний очевидцев предприняли попытку осветить цикл аграрной политики СССР, начиная с посевов и до периода планирования в 1931 году. Большинство западных ученых делают заключение о том, что политика коллективизации И.В.Сталина специально проводилась против украинцев и других национальных групп ${ }^{9}$.

Труды австралийца С. Уиткрофта «Советская статистика о продовольствии и смертности в период голода 1917-1922 и 1931-1933 гг.», итальянского исследователя Николо Пианчиола «Голод в степи. Коллективизация сельского хозяйства и казахских скотоводов», французского историка Изабель Огайон «Седентаризация казахов СССР при Сталине. Коллективизация и социальные изменения (1928-1945 гг.)», книги Н.М. Неймарка «Геноциды Сталина» и Шейлы Фицпатрик «Сталинские крестьяне: социальная история Советской России в 30-е годы: деревня» были использованы в качестве необходимых источников информации для нашего исследования ${ }^{10}$.

При написании статьи применялись историко-системный, историко-сравнительный, хронологический, исторический, историко-социальный методы исследования, а также метод наблюдения и другие.

Обсуждение. Один из периодов отечественной истории, требующий повторного изучения и исследования с теоретикометодологической точки зрения - это борьба казахского народа за свободу. Настало время, когда проводить исследования восстаний нашего народа против колониальной политики нужно в новом

\footnotetext{
${ }^{7}$ https://e-history.kz/kz/contents/view/925

8 https://e-history.kz/kz/contents/view/925

${ }^{9}$ https://e-history.kz/kz/contents/view/925.

${ }^{10}$ https://e-history.kz/kz/contents/view/925 
формате. Здесь, на наш взгляд, есть ряд актуальных вопросов, на которые следует обратить внимание в первую очередь.

В истории разных народов в тяжелые времена появлялись свои герои. К примеру, из башкирского народа против российской колониальной политики впервые в 1755 году восстал Абдолла Алиев, позже его дело продолжил Салават Юлаев. У подножия Кавказских гор сплотили дагестанский народ и повели на борьбу Шайх Мансур и его последователь имам Шамиль. В Мексике это Мигель Идальго-и-Костилья и Хосе-Мария Морелостар, погибшие в ходе борьбы против испанских конкистадоров, позже их дело продолжил Бенито-Пабло Хуарес. Это и известный предводитель осводительного движения алжирского народа против французского гнета Абд-аль Кадир и другие сильные, несгибаемые личности. Почему в числе таких известных всему миру героев других наций, нет имен наших национальных героев?

Среди них особого упоминания заслуживают имена Сырыма Датулы и других людей, стоявших в авангарде многовековой борьбы казахов против русского колониализма. Пора заявить о том, что он равнозначная фигура с вышеназванными деятелями. Жизнь и деятельность Сырыма совпали с началом всестороннего укрепления Российской империи, приращения ее территории. Очевидно, что пример такой самоотверженной борьбы спустя века сделал возможной нашу Независимость.

Начало первой мировой войны 1914 года и привлечение в войну царской России еще больше увеличило налоги, налагаемые на российскую колонию. Если согласно положению от 25 марта 1891 года налог, уплачиваемый кочевыми казахами, составлял 4 рубля, то в октябре 1914 года был издан указ о том, что на кочевых казахов, не исполнивших воинскую повинность, накладывался военный налог в размере 4 рублей. То есть теперь размер налога, собираемый с каждого дома, вырос до 8 рублей. Некоторые казахские семьи были не в состоянии выплачивать такой налог.

В результате вытеснение казахских крестьян с родной земли, разрушение их хозяйства, а тем более увеличение размера налогов стало причиной того, что казахи стали движущей силой восстания 1916 года, причем казахи превосходили по численности.

Если число призывников согласно указу от 25 июня 1916 года о призыве казахов на тыловые работы фронта из Атбасарского уезда составило 5 тыс. человек в возрасте от 19 до 31 лет, общее число призывников по Акмолинский области было зарегистрировано в количестве 11870 человек. В целом в уезде проживало 98274 казахов из 126 сел 26 волостей. Согласно списку людей, 
привлекаемых царской администрацией на тыловые работы по Акмолинской области в уезде было 47 волостей, 289 сел, в которых проживало 211280 человек. То есть, по сравнению с численностью жителей Атбасарского уезда население было больше в полтора раза. Из числа, указанного в переписи населения 25815 человек были люди призывного возраста, из которых 9000 человек должны были быть отправлены на тыловые работы в первую очередь. ${ }^{11}$

Казахи, целью которых было неповиновение указу, поступившему сверху, начали группироваться по племенному признаку, стали избирать своих ханов и вооружаться. В частности, воины волостей, относящихся к племени аргын стали готовиться к открытому сражению и избирать воинов. Многочисленное войско возглавили мулла Балкожа, бай Жакал Мырзакожин, Хасен Жанибеков, а также Ашыгайулы Жусип из племени бабас, ему было за шестьдесят. Решившие для себя, что не пустят мужчин исполнять воинскую повинность и что лучше погибнуть в сражении с царским войском, около 800 воинов собрались у подножия горы Жыланды. ${ }^{12}$

Вооруженное нападение восставших на русских рабочих Карсакбайского, Жезказганского, Байконырского предприятий началось после 20 июля. В сведениях начальника Атбасарского уезда от 16 августа говорится, что в 70 километрах восточнее от Улытау собралось около 7 тысяч восставших. ${ }^{13}$ Увеличение рядов восставших и их вооружение показало царской администрации, что реализация указа мирным путем, без кровопролития невозможно. Он сообщил об этом в своей телеграмме от 18 июля, адресованной генералугубернатору степного края, Министру внутренних дел Б.В. Штрюмеру, в которой подчеркивалось: «были предприняты меры по подавлению беспорядков и обеспечению безопасности русских».14

Был создан карательный отряд под командованием полковника Иванова - атамана карательного военного подразделения. В состав этого подразделения вошли 2 отряда пехотинцев и 1 конный отряд, было также 2 пулемета. Вместе с тем, в Омск из Атбасара дополнительно были доставлены 150 винтовок, 20 ящиков с патронами. Помощник военачальника военного округа генерал Яготкин

\footnotetext{
11 ПР РК, фонд 811, т. 1-80, дело 15, с. 94 (Памятник И.В. Дееву), 12 ПР РК, фонд 811, т. 6, дело 233, с. 27 (Памятник С. Искакову).

13 ОГААО, фонд 427, т. 9, дело 53, с. 533 (Протоколы Атбасарского уездного партийного комитета).

14 Фонд редких рукописей центральной научной библиотеки НАН РК, 1019 том, 1013 том, с. 512 (Материалы экспедиции, посвященной 20-летию восстания 1916 года под руководством академика А.Х. Маргулана, писателя С. Шарипова 1916 года). 
приказал начальникам гарнизонов обеспечить казаков стрелковым оружием в полном объеме для подавления восставших. ${ }^{15}$

Восстание казахов смежного Акмолинского уезда сразу быстро разрослось во всенародное. Так как начало восстания пришлось на период переселения казахов на летовки, расположенные вблизи рек Нура, Есиль, Куланотпес, Жарлы, Талды, их борьба за освобождение была тесно связана с восстанием казахов Атбасарского уезда.

Казахи Акмолинского уезда открыто выразили свое несогласие и неповиновение с царским указом от 25 июня и стали вооружаться. Нельзя было найти ни одного казаха, который бы исполнил указ по своей инициативе: все мужчины 7 волостей племени тама, 4 волостей племени кыпшак, 5 волостей племени тинали, 11 волостей племени акимбай, 4 волостей племени темеш, 5 волостей племени керек, 2 волости племени канжыгалы, которые могли держаться в седле, твердо решили умереть во время сражений на родной земле. С.С. Сейфуллин, видевший выражение лиц людей, вышедших на борьбу, так описал ход событий в романе «Тар жол, тайғақ кешу»: «У нас не будет лучшей мечты, чем умереть в борьбе с русским царем, который отобрал у нас землю, воду, а теперь дошел и до нас самих». Все население приготовилось к сражению, вскочив на своих лошадей. Мужчины стали выходить группами, обнажая свои боевые секиры и копья. Но, как бы там ни было, мощной поддержки у них не было». ${ }^{16}$

Политика империи на региональном уровне была слишком медленной по сравнению с политикой в центре, чтобы изолированные от внешнего мира казахские села не пострадали от Февральской революции, вызванной кризисом. И. Кумач и Ф. Калюта в работе «В акмолинских степях» писали: «Февральская революция пришла в Атбасар с опозданием и не принесла особых изменений. Старая казахская администрация все еще сохраняла свою власть. Только в апреле было организовано земское управление» ${ }^{17}$. Это указывает на то, что в Атбасар, административный и политический центр уезда, весть о революции не дошла вовремя. Член Атбасарского революционного комитета Г.Ф. Иванов в своих воспоминаниях писал: «Весть о Февральской революции распространилась по Атбасару, а прежняя власть осталась прежней в городе и районе»18.

\footnotetext{
15 Восстание 1916 года в Средней Азии и Казахстане. Документы и материалы. Москва: Наука, 1960, с. 94.

${ }^{16}$ СЕЙФУЛЛИН, С.С.: Тар жол, тайғақ кешу. Алматы: Жазушы, 2009, с. 84.

17 Восстание 1916 года в Средней Азии и Казахстане. Документы и материалы. Москва: Наука, 1960, с. 510.

18 Журнал совещания о землеустройстве киргиз. С. Петербург, 1907.
} 
Многие казахи приветствовали известие о свержении императора. Была уверенность, что новое правительство перестанет нанимать нелегальных рабочих и наступит мир. 15 июня 1917 года около 15 представителей большевиков Атбасарского района, в том числе Х. Сандыбаев, Х. Бекходжин, И. Толеубаев, О. Жанайдаров и другие, направили телеграмму председателю исполкома Государственной думы в Санкт-Петербурге. «Сегодня, услышав о манифесте, прочитав в местной мечети Коран и попросив у Аллаха мощи Российской державе, мы считаем своим священным долгом быть рядом с вами. Мы признаем новое правительство. Мы ожидаем от него справедливости, равенства и свободы в политических и экономических отношениях», - говорилось в телеграмме ${ }^{19}$.

Такого рода документы, которые часто встречаются в архивах, показывают, что партийные работники восприняли сбор налогов как «войну». Теперь областная продовольственная комиссия поручила губернским комиссиям принимать самые решительные меры, в неподчиняющиеся волости и села направить воинские части и ревизионный суд. Крестьяне также были предупреждены, что воинские части будут отозваны, если они будут вовремя платить налоги, а инспекторы будут привлечены к ответственности, если налоги не будут собраны должным образом 20.

«Фронт» сбора налогов использовался для запугивания партийных работников. 27 октября 1921 года решением губернского совнархоза Верховному суду было передано дело людей, отказавшихся идти на продовольственный фронт и не подчинявшихся решениям губернского исполнительного комитета ${ }^{21}$. Таким образом, когда бедные казахские семьи не могли выплачивать налоги и сборы, партийным работникам не оставалось ничего, кроме как забирать то, что у них было.

Выполнение строгих указаний сверху превратилось в кампанейщину. 9 октября 1921 г. партийный комитет Атбасарского уезда в обращении ко всем ячейкам заявил, что «девизом сегодняшнего дня должна быть всемерная помощь центру» 22 . Кое-где были допущены перегибы. В 1922 году Красный караван в информации о посещенных районах сообщал, что Акмолинский областной продовольственный комитет первоначально удвоил размер установленного налога, в результате чего в 1921 году 90\%

\footnotetext{
${ }^{19}$ Киргизское хозяйство в Акмолинской области T-V. C. Петербург, 1910.

${ }^{20}$ Сельскохозяйственный обзор Акмолинской области за 1915 г. Омск, 1917.

${ }^{21}$ Обзор сельскохозяйственный жизни заселяемых районов Азиатской Россий за 1913

2. С. Петербург, 1914.

22 Экономическая жизнь Киргизского края. 1921 г.
} 
всей сельскохозяйственной продукции составляли только молоко и сено без хлеба 23.

Сборщики налогов, в руках которых были высшие полномочия, вышли в народ и, наряду с использованием оружия при выполнении возложенных на них обязанностей, допускали различные своевольные и недисциплинированные поступки. В информации о политической ситуации уезда в январе - феврале 1921 года Атбасарское уездное управление не скрывало того факта, что нетактичное отношение сборщиков налогов с местным населением, неумение установить с людьми конструктивное взаимодействие и их грубое обращение с народом вызывали акты протеста и волнений в уезде. ${ }^{24}$

Продолжение имеющих место во времена царского правительства политики превосходства в казахских селах, узурпаторства, насилия и бесчинства еще больше возмутили и довели народ до отчаяния. Казахи убедился в том, что девиз большевиков «равенство, свобода, справедливость» это всего лишь пустые слова.

Таким образом, выражению сопротивления продовольственной политике правительства способствовало насилие сборщиков налогов и милиционеров. Конечно, большая часть участников восстания - это бедняки, лишившиеся последнего вследствие сдачи налогов. На заседании бюро Акмолинской губернии, проходившем в конце апреля 1921 года ясно было сказано о том, что «большинство участников восстания - бедняки-казахи, они страдают от голода и получают помощь не от советской власти, а напротив, от кулаков». 25 Несмотря на то, что на заседаниях бюро Акмолинской губернии и срочных сообщениях краевого военного чрезвычайного комиссариата направленных в Москву открыто сообщалось о том, что большинство участников восстания - голодные бедные казахи и что они, объединяясь меж собой, поддерживают бандитов на местах, на повестку дня стал подниматься вопрос «борьбы с бандитизмом» и рассматривались пути его подавления.

Восставшие против советской власти северного и юго-восточного побережья Атбасарского уезда воссоединились с контрреволюционными силами, сгруппированными на земле Акмолинского уезда. Этому в значительной степени способствовало проведение агитационно-пропагандистских мероприятий контрреволюционными организациями среди казахов. Политическое бюро при Ак-

\footnotetext{
${ }^{23}$ Известия Киргизского областного комитета. 1922 г.

${ }^{24}$ АМИРКЫЗЫ, К.: Мой аул - моя родина. Акмола, 1993, с. 14.

${ }^{25}$ АЛДАЖУМАНОВ, К.: Крестьянское движение сопротивления. Алматы: изд. АрысКазахстан, 1998, с. 6.
} 
молинской уездной милиции 14 июня 1921 года в телеграмме, адресованной начальникам милиции всех районов сообщало о том, что в уезде появились бандиты, что ведется контрреволюционная пропагандистская работа и что они создали единую организацию и был обозначен вопрос борьбы с ними. Потерпевшие поражение от Красной армии и бежавшие силы казачье-русской армии беспорядочно передвигаясь, смешались с народным движением Акмолинского уезда. В некоторых местах казахи стали присоединяться к малым войскам под предводительством офицеров Колчака и участвовали в сражениях с Красной армией.

Казахские села потерпели много ущерба и страданий от банд, состоявших из казахов и русских. Имущество беззащитных сел забирали блуждающие по степи воины для своего пропитания. После того, как была разгромлена основная часть контрреволюционных сил, в Акмоле был создан карательный отряд, состоящий из 90 человек, принявшийся уничтожать малые отряды повстанцев-казахов. В сражении с казахами волостей Есиктай и Бугылы погибло около 70-ти казахов, остальные были вынуждены бежать. Также когда карательные силы обходили волости Кандымай, Сарытобе, Сарышын «...по неизвестным причинам было расстреляно 32 казаха». 26 Повторно был использован главный способ подавления восставших, использованный в 1916 году - кровопролитие, применяемое по отношению к народу. Таким образом, вооруженное войско, вышедшее в народ ловить «банды», забрало жизни многих безвинных людей. После открытого истребления тех, кто восстал против продовольственной политики большевиков, Красная армия держала остальных в вооруженных оковах, не давая никому свободу действий и волеизъявления.

30 августа 1920 года на экстренном совещании ответственных работников революционного комитета в Атбасаре обсуждался вопрос о том, что «контрреволюционные силы превратили Аргынский район и Улытау в свой штаб и что они, организовав народ, оказали сопротивление армии под предводительством Вохра» и вынесено постановление об увеличении в указанных районах штата милиции. ${ }^{27}$

Колониальное господство царской России, способствовавшее восстанию народа и такая же ситуация, имевшая место во время правления советской власти - так называемая общая преемствен-

\footnotetext{
${ }^{26}$ Казахстан в начале ХХ века: методология, историография, источнико ведение. Сборник статей. Выпуск II. Алматы, 1994, с. 3.

27 БЕКМАГАНБЕТОВ, О.Ж.: Ханство Баганалы хандығы. In: Bопросы истории Казахстана. Исследования молодых ученых. Алматы: "Білім" баспасы, 2000, с. 24.
} 
ность власти - вызвала протест народа. Выдающийся деятель казахского народа С. Садвакасов писал: «Наследие, оставшееся после самодержавия на этой казахской земле - это то, что казахи считают своими врагами представителей власти» - это было мнением, возникшим на основе понимания отношения местного народа к большевикам. ${ }^{28}$

Продовольственная политика советской власти стала серьезным ударом, способствовавшим разрушению и без того обветшалого хозяйства казахских сел, подвергавшихся в течение определенного время нападению. Сотрудники партии, приступившие к выполнению намеченного продовольственного плана, отбирали у народа последнее, это было похоже с ситуацией притеснения казахских аулов от сборов и налогов во время Первой мировой войны. Правительство не учитывало тот факт, что одной из причин восстания было то, что налоговая политика 1916 превзошла все границы.

Казачьим и русским крестьянам, которым во время советской власти вновь были предоставлены привилегии и помощь, как и во времена царского правления, все же не могли отказаться от своих воззрений, сформированных во время восстания 1916 года.

Межнациональные распри были и между местными сотрудниками партии. Известно, что такой национальный вопрос, обостренный со времен царской России, советская власть решала с точки зрения великой русской политики.

Причиной вооруженного восстания народа стали схожие черты колониальной политики, ставшей причиной национально-освободительного движения 1916 года, с политикой советской власти.

Противодействие колониальной политике всякий раз оканчивалось поражением. Воспрепятствование народа правлению большевиков и их продовольственной политике также были нещадно подавлены вооруженным методом. Таким образом, во главе восставших в 1916 году в Атбасарском и в 1922 году в Акмолинском уездах были известные личности, пользовавшиеся доверием народа, которые во имя будущего поколений, во имя и в интересах народа стали борцами за справедливость.

Это чувствовал всей душой каждый представитель нации. Не участвовавшие в переворотах за власть в центре метрополии и использовавшие в своих интересах послабление колониального аппарата авторитетные лидеры казахов стали насторожено и внимательно следить за происходящим. Ханская власть смогла стать защитником народа. Однако спустя немного времени большеви-

28 Экономическая жизнь Киргизского края. 1921 г., с. 149. 
ки, прочно захватившие власть, сразу дали понять, что не станут лишаться влияния на колониальные народы России. Схожесть проводимой политики существенно отодвинула мечту казахской нации о свободе, напротив, стали видны признаки колониального гнета. Это стало логическим продолжением восстаний, не раз имевших место до этого времени в нашей отечественной истории.

Выводы. Подытоживая наше исследование, мы сделали следующие заключения:

Во-первых, отношение простых людей к новой власти и процессу ее принятия, а также тип сопротивления (закалывание скота, откочевка в другую местность, поджог складов и т.д.). Поэтому сопротивление простого народа следует рассматривать с высоты принципа «Что Советская власть дала народу?».

Потому что сведения подтверждают тот факт, что после издания июньского царского указа 1916 года среди восставших против указа сформировалось общее мнение: «ради чего мы должны давать царю людей для выполнения физических работ? За какие его заслуги и за какие его благодеяния?». В итоге народ и словом, и делом доказал, что не хочет повиноваться и исполнять Указ. В истории был такой выбор народа.

Известно, что кочевой народ бескрайней степи признавал только одну форму власти - ханскую власть, веками существовавшую в истории. В понятии народа ханская власть была сродни государственности, своеобразным символом независимости и этот вид правления всегда был в памяти народа, никогда не угасал и всегда проявлялся как единственно правильная форма правления, вновь и вновь возрождаясь в разные исторические эпохи. Доказательством тому является тот факт, что в 20-30-е годы XX века в каждом уголке Казахстана из числа восставшего народа избирался хан.

В качестве примера можем отметить следующие события: в 1921-22 годах воины под предводительством Кейкі Кокембайұлы, пребывавшие на территории Торгайского и Атбасарского уездов, избрали ханом Кулсеита потомка Бабыра, а в 1929-31 годах в западном регионе избрание восставшими Алниязова Тобанияза, прозванного «Ханом адая», избрание восставшими Каракума ханом Байымбетова Жумагазы, после его пленения назначение ханом Жубанова Копжана, также можно назвать Султанбека Шолакова, избранного ханом во время Созакского восстания и др. В этом отношении большую роль играют воззрения политически грамотных, досконально знающих и изучивших суть дела представителей казахской интеллигенции. 
Также необходимо разграничить понятия «власть большевиков» и «русская власть» бытовавших в то время в народном понимании.

Вывод, который можно сделать в этой связи - советская власть проявляла недоверие славным воинам-героям восстания 1916 года и целенаправленно приступило к их задержанию. Представители новой власти поняли, что народ признает ханскую власть и может сплачиваться под ее руководством. С первых лет правления советской власти - ещё перед задержанием представителей казахской интеллигенции - изгнанию подверглись руководители восстания 1916 года.

В начале 1920 года хан Аргынского ханства О. Шолаков и тысячник К. Алтынсарин, обвиненные как «...действовавшие против правительства», были осуждены и направлены сначала в Семипалатинск, а затем сосланы в Сибирь. Хан Баганского ханства Касен Каскабайулы в 1928 году был в числе тех крупных баев, чье имущество, в том числе и скот, были конфискованы и был сослан за пределы Казахстана на три года. Его потомки только после обретения независимости смогли вернуться на историческую родину из Узбекистана. Хана кипчакского ханства А. Жанбосынова постигла та же участь.

События 1916 года показали, что мужи народа, почитаемые и пользующиеся авторитетом, в любой момент могли сплотить и повести за собой народ.

Во-вторых, взаимосвязь между народным движением, полностью объявшим по масштабу территорию национальной республики, одевшей хомут советской власти, и представителями казахской интеллигенции. В том числе позиции алашординцев, перешедших на сторону большевиков после объявленного им прощения, оценка простого народа, данная советской власти. Несомненно, что представители интеллигенции, не оставались равнодушными, видя, как свой родной народ вновь попал на растерзание. Из следующих исследований стало известно, что власть использовала ряд активистов того времени под предводительством бывших у власти А. Жангельдина, С. Сейфуллина, Г. Мусрепова для проведения переговоров с восставшими с целью подавления восстания в Каракуме.

B-третьих, при поднятии темы национально-освободительного движения казахского народа умалчивается борьба казахов за рубежом, особенно соотечественников, переехавших в Китай, Монголию, Афганистан, Индию. Необходимо определить общие закономерности, связанные с народной борьбой на родной земле.

B-четвертых, известно, что в 5-ти томнике "История Казахстана", считающемся путеводной звездой истории Казахстана, докла- 
дываются восстания казахов, описания которых заканчиваются пояснением «историческое значение». Вместе с тем, дополнительного исследования требуют такие вопросы, как оценивал восстание народ, восхваление и возвеличивание геройства руководителей, участников восстаний, пропаганда, даже возрождение. Так как известно, что в памяти народа такие великие события и вожди не забывались, а становились методом пропаганды, которое давало импульс для дальнейшей борьбы.

В-пятых, такие методы, как проведение репрессивной политики колонизаторской администрацией после народных восстаний и борьбы, преследование самих активистов восстаний и членов их семей, их близких и родных, предложение денег в обмен на поимку активистов освободительных движений - полностью должны быть описаны при изложении истории восстаний тех лет. Предложение денег за поимку вождей нации является уловкой, применяемой в практике развитых стран мира по сегодняшний день.

В-шестых, желательно перевести на другие языки исследования, воспоминания и документы о казахской освободительной борьбе. Потому что бесспорно то, что другие народы мира, находящиеся под гнетом колониализма, поймут, что казахи были в такой же ситуации, как и они, и смогут понять на каком уровне был характер восстания против колониальной политики русского народа и ее особенности.

Если не будут разрешены вышеуказанные вопросы, они всякий раз будут представать в ходе исследований ученых и будут оказывать негативное воздействие на оценку народной борьбы при поиске причин национально-освободительных восстаний. Вместе с тем, исследование данного вопроса в Латинской Америке, Африке, странах Юго-Восточной Азии не должно оставаться без внимания.

Исходя из вышеизложенного необходимо отметить, что история многовекового освободительного движения нашего народа является важным звеном казахской национальной истории.

\section{Zhrnutie:}

\section{Povstania v Kazachstane proti cárskej vláde v roku 1916 a soviet- skej politike v rokoch 1921 - 1922: analógia a špecifiká (na zákla- de materiálov Akmolinského a Atbasarského ujezdu)}

Vo svojej štúdii autori poukazujú predovšetkým na príčiny, ktoré viedli k vypuknutiu povstaní v Kazachstane v rokoch 1916 a 1921 - 1922, súčasne analyzujúc nálady širokých más - hybnej sily národno-osloboditel'ských povstaní 
v krajine v uvedených obdobiach. Prvé z nich sa odohralo v období účasti Ruského impéria v I. svetovej vojne a hlavnými dôvodmi revolty proti cárskej administratíve $\mathrm{v}$ Kazachstane boli faktory sociálno-ekonomického a politického charakteru: posilnenie koloniálneho útlaku a odoberanie pôdy, zvýšenie daní a odvodov, vykorist'ovanie Kazachov a politika rusiifikácie, celkovo tak zhoršenie sociálnej situácie. Bezprostredným impulzom bol cársky dekrét z 25. júna 1916 o mobilizácie mužského obyvatel'stva Kazachstanu (100 tis.), resp. Strednej Ázie (400 tis.) do armády na tylové práce. Na začiatku živelné povstania napokon prerástli v celonárodné povstanie Kazachov a boj za nezávislost'. Revolúcia a rozpad Ruského impéria v roku 1917, nasledujúca občianska vojna a nastolenie bol'ševickej politiky vojnového komunizmu (a v tom potravinovej diktatúry) nad’alej prehlbovali zložitú sociálnu situáciu Kazachov, ktorým sa odoberali všetky pol'nohospodárske výrobky a konfiškoval sa dobytok, čo napokon viedlo k hladomoru $(1919$ - 1922). Bol'ševické rekviračné metódy boli Kazachmi vnímané ako lúpež a spôsobili zvýšenie nespokojnosti, ktoré opätovne prerástlo do ozbrojeného povstania v Kazachstane v rokoch $1921-1922$. Autori uvádzajú konkrétne historické fakty, založené na najnovších archívnych výskumoch a rekognoskácie historických zdrojov. V závere štúdii analyzujú vnútorné súvislostí povstaní proti cárskej nadvláde v roku 1916 a nastolenej sovietskej politike v krajine začiatkom 20. rokov 20. storočia a odhal'ujú analogické črty a špecifiká skúmaných udalostí. 